УДК 619:616-072:591.441:636.7

(C) 2015

\author{
Локес П. І., доктор ветеринарних наук, \\ Кравченко С. О., кандидат ветеринарних наук
}

Полтавська державна аграрна академія

\title{
УЛЬТРАСОНОГРАФІЯ СЕЛЕЗІНКИ У СОБАК
}

\section{Рецензент - доктор ветеринарних наук С. М. Кулинич}

У роботі представлені результати наукового дослідження щзодо вивчення ультрасонографічних ознак нормальної селезінки та за ї̈ патологічних станів у собак. Описано методику ультразвукового дослідження селезінки у тварин даного виду та охарактеризовано зміни візуалізаиії органу. Наведені ультрасонографічні характеристики селезінки за спленомегалії, крововиливів у ї̈ паренхіму, за розриву капсули та неоплазіі. Встановлено, щзо у здорових тварин селезінка має форму стрічки або півмісяия з гострими краями та однорідною дрібнозернистою нормоехогенною паренхімою.

Ключові слова: ультрасонографія, собаки, селезінка, патологія, діагностика.

Постановка проблеми. Селезінка є важливим внутрішнім органом, функції якого до кінця не з'ясовані. Вона реагує на більшість патологічних процесів в організмі. Найбільш типовою реакцією селезінки є спленомегалія, яка може бути як фізіологічною (депонування частини крові), так $\mathrm{i}$ патологічною - за гемолітичних процесів, інфекційних, паразитарних захворювань, а також токсикозу $[2,5,9]$. У спеціальній літературі описано переважно загальноклінічні методи дослідження цього органу, зокрема пальпація (у коней та собак), перкусія (у великої рогатої худоби) та діагностична пункція селезінки. Проте, як зазначають автори, інформативність таких досліджень сильно обмежена і $\epsilon$ інформативною лише за вираженої спленомегалії. Впровадження порівняно нових, додаткових спеціальних методів діагностики, зокрема ультрасонографії, надає можливість отримання точної і детальної інформації щодо топографії, структури та розмірів селезінки як у клінічно здорових, так і хворих тварин. Тому дослідження у цьому напрямі $є$ актуальними.

Аналіз основних досліджень і публікацій, у яких започатковано розв'язання проблеми. Ультрасонографія $\epsilon$ інформативним методом діагностики патологічних станів селезінки $[1,3$, $7,8]$. Літературні дані щодо ультрасонографічного дослідження селезінки у тварин, зокрема собак, суперечливі і розрізнені. Іноземні видання висвітлюють переважно ультрасонографічні характеристики селезінки клінічно здорових тва- рин та описують зміни органу, здебільшого за спленомегалії або новоутворень [6]. Вітчизняні видання [4] надають інформацію щодо структури паренхіми та містять окремі дані щодо топографії органу у нормі та за патології. Все вищевказане зумовлює доцільність подальших наукових досліджень у цьому напрямі.

Мета досліджень - встановити топографію та дослідити ультрасонографічні характеристики селезінки у клінічно здорових собак та тварин за спленопатій.

Основним завданням було ультразвукове дослідження селезінки клінічно здорових та хворих собак різних порід (mini, medium, maxi, giant).

Матеріали і методи досліджень. Дослідження проводили в умовах кафедри терапії Полтавської державної аграрної академії у період з 2010 по 2015 роки. Матеріалом для досліджень слугували клінічно здорові та хворі собаки. У ході виконання роботи використано результати досліджень десяти клінічно здорових та 22 хворих тварин. Встановлений діагноз підтверджували лабораторними дослідженнями, або під час оперативних втручань чи секційно.

Досліджуючи клінічно здорових та хворих собак, застосовували загальноклінічні методи огляд, пальпацію, перкусію, аускультацію, термометрію. Враховували анамнестичні дані. Усі досліджені тварини належали жителям м. Полтава. Після клінічного дослідження застосовували оглядову ультрасонографію органів черевної порожнини, звертаючи увагу на топографію та ультрасонографічні характеристики селезінки. У процесі досліджень використовували ультразвуковий сканер SonoScape A6 vet (виробництво КНР) із секторним датчиком частотою 2-6 мГц. Тварин розміщували дорсовентрально або на правому боці. Акустичне вікно створювали шляхом видалення шерстного покриву на вентральній черевній стінці від мечоподібного відростка до ділянки паху.

Результати досліджень. У клінічно здорових собак селезінку візуалізували у лівій частині черевної порожнини у ділянці, обмеженій лівою ниркою (дорсокаудально), дном шлунка (дорсо- 


\section{ВЕТЕРИНАРНА МЕДИЦИНА}

краніально), ободовою кишкою (дорсально) та черевною стінкою (вентрально). Селезінка таких собак мала дрібнозернисту гомогенну структуру паренхіми, ехогенність дещо вищу за паренхіму печінки, була чітко окреслена гіперехогенною капсулою. Вона мала форму стрічки або півмісяця 3 гострими краями, які добре контурували завдяки гіперехогенності капсули селезінки.

Переміщуючи датчик каудокраніально, розрізняли гострий каудальний край, краніальніше товщина органу збільшувалась, в окремих випадках візуалізували неглибоку поперечну вирізку у краніальній третині органу, і нарешті краніальну частину органу, яка була ширшою за каудальну та мала гострі гіперехогенні краї.

У середній третині селезінки, 3 вісцеральної поверхні візуалізували ворота селезінки (гіперехогенну ділянку навколо місця занурення артеpiï селезінки та виходу селезінкової вени) та анехогенні артерію та вену селезінки, які розгалужувались у товщі органу. Головний (краніальний) край селезінки прилягав до печінки, що давало змогу порівняти їх ехогенну структуру.

Патологічними станами селезінки, які відбивались на iї сонографічній будові, були спленомегалія (40,9 \% випадків), крововиливи у паренхіму селезінки $(31,8 \%)$, розриви капсули селезінки (18,2\%) та новоутворення селезінки $(9,1 \%)$. У даній статті ми не зупиняємось на етіології та патофізіології спленопатії, приділяючи увагу передусім сонографічним характеристикам селезінки.

За спленомегалії найбільш виразними ознаками $\epsilon$ збільшення товщини паренхіми органу та відносне зменшення іiі ехогенності (рис. 1).

Це пояснюється кровонаповненням судин та синусів селезінки, що збільшує відстань між ехогенними структурами (стінками судин та строми) органу і тим самим підвищує проникність звукових коливань. Краї селезінки, у першу чергу краніальний, а згодом і каудальний, за спленомегалії стають заокругленими, а магістральні судини - розширеними внаслідок гіперемії.

Унаслідок політравми, у окремих випадках, сонографічно виявляли крововиливи у паренхіму селезінки та розриви капсули (рис. 2).

Геморагічні осередки у селезінці виглядали як анехогенні або гіпоехогенні утворення, навколо яких паренхіма селезінки була набряклою, неоднорідної ехогенності (рис. 2, а). У випадках розривів капсули селезінки місце розриву ідентифікували як порушення гіперехогенного контуру капсули у ділянці країв або воріт органу (рис. 2, б). Поряд із місцем розриву капсули візуалізували невелику кількість вільної рідини, що розцінювали як ознаку кровотечі у черевну порожнину (рис. 2, в)

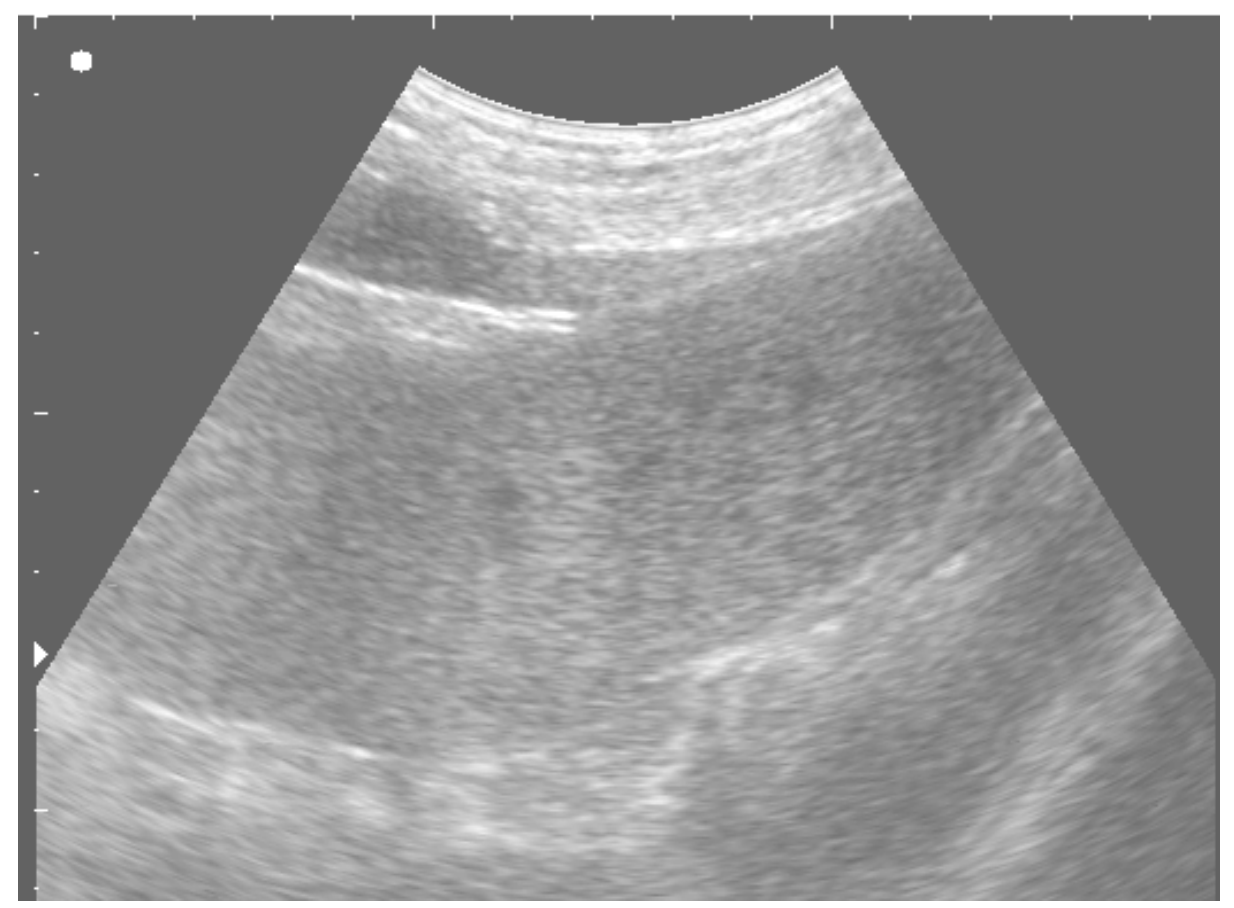

Рис. 1. Ультрасонограма селезінки собаки за спленомегалії 


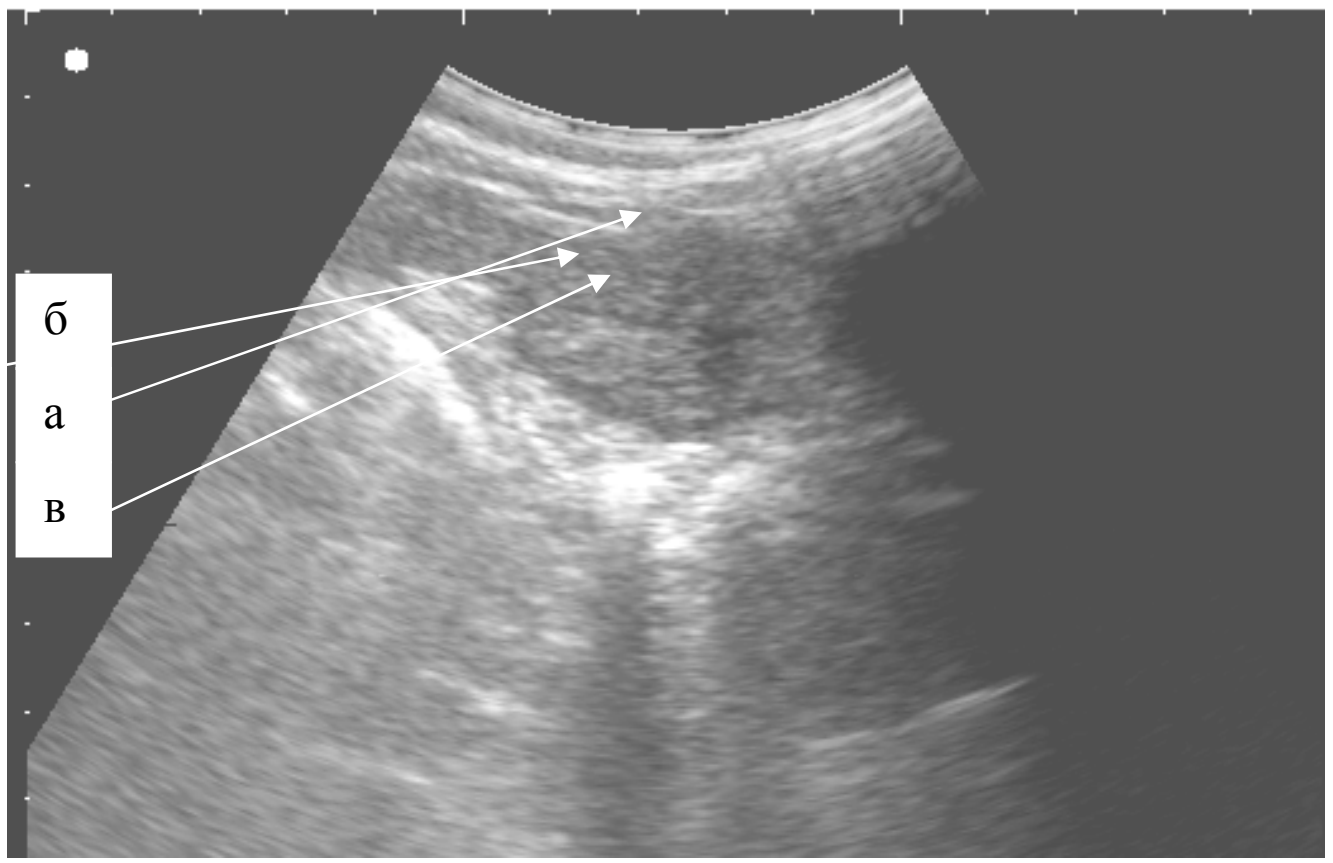

Рис. 2. Ультрасонограма селезінки за крововиливу у паренхіму: $а$-місце крововиливу; б-розрив капсули селезінки у ділянці воріт; в - вільна рідина у місці розриву капсули

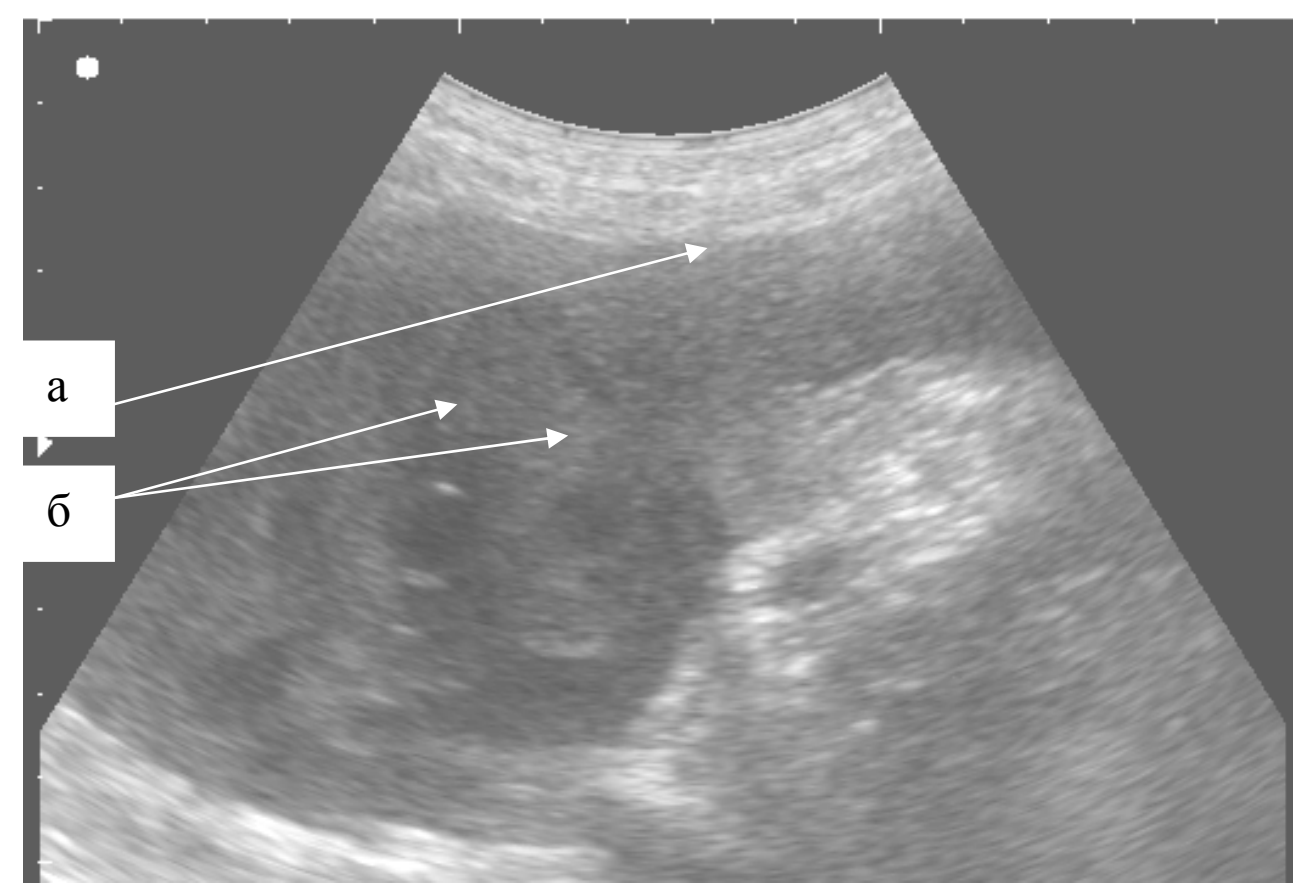

Рис. 3. Ультрасонограма селезінки за фокальної неоплазї̈: а-незмінена паренхіма селезінки;

\section{б-метастази}

Одним 3 патологічних станів селезінки, що візуалізуються сонографічно, $є$ новоутворення. За даними літератури, селезінка є органом, який першим затримує патологічні клітини пухлин, що з часом розростаються і створюють поодинокі чи множинні осередки у паренхімі (метастази). До таких пухлин, у першу чергу, відно- сять лімфому та новоутворення молочної залози $[6,9]$. В цих випадках паренхіма селезінки не змінює своєї ехогенності, за виключенням фокальних уражень, розташованих нерівномірно (рис. 3). Ці осередки, як правило, мали ехогенність меншу за ехогенність паренхіми селезінки (рис. 3, б). 


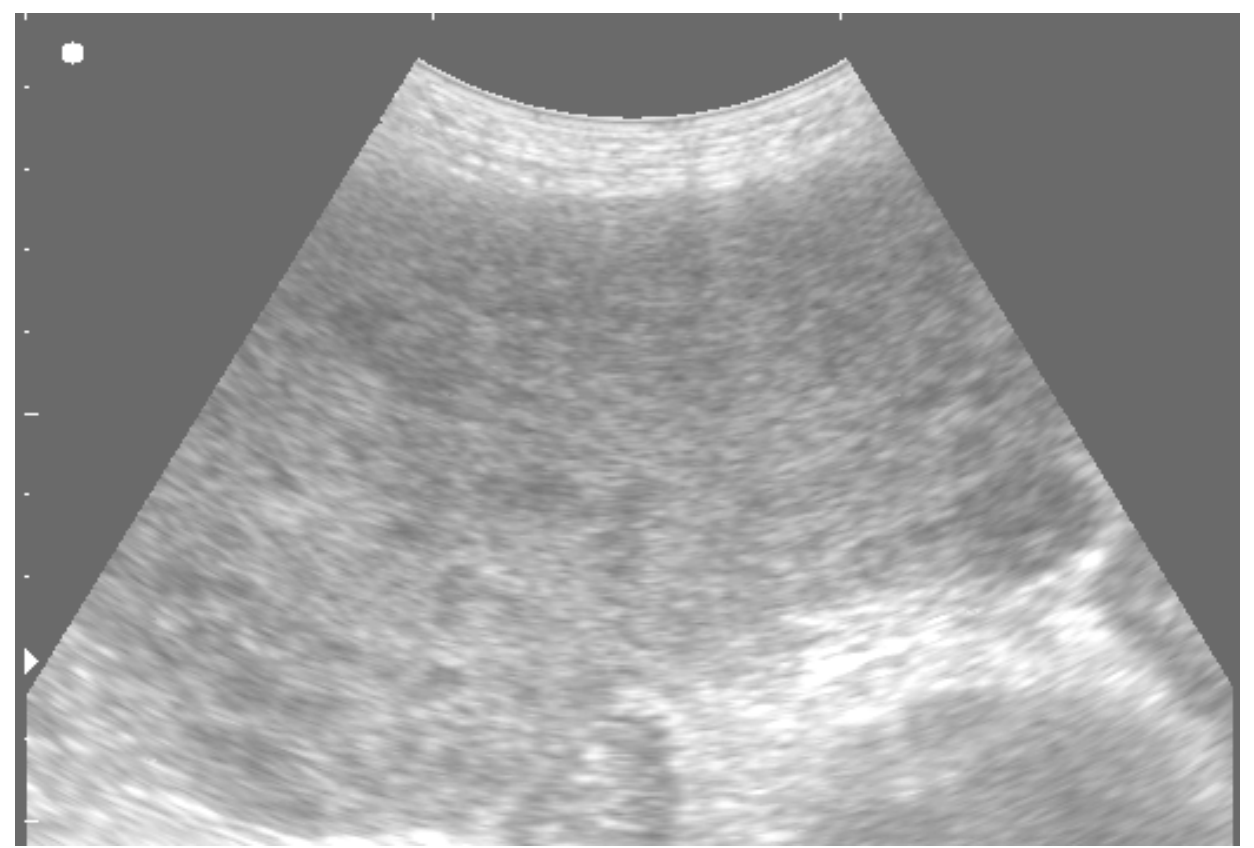

Рис. 4. Ультрасонограма селезінки собаки за дифузної неоплазії

Також реєстрували дифузні неоплазії селезінки, коли ураженою була вся візуалізована паренхіма органу (рис. 4). У таких випадках селезінка мала нерівні контури, краї органу були заокругленими, загальна ехогенність паренхіми підвищена 3 множинними гіпо- та ізоехогенними осередками різного розміру - від 0,7 до 10 мм. Слід зазначити, що визначення морфології новоутворень селезінки ультрасонографічно $є$ неможливим, тому даний аспект проблеми потребує подальших до-

\section{БІБЛІОГРАФІЯ}

1. Берестень Н. Ф. Значение ультразвукового исследования в оценке абсолютных и относительных размеров селезенки при гематологических заболеваниях / Н. Ф. Берестень, А. С. Глускер, А. И. Нартов // Ультразвуковая диагностика. 2002. - №2. - С. 197-198.

2. Клінічна діагностика внутрішніх хвороб тварин / [Левченко В. І., Влізло В. В., Кондрахін І. П. та ін.] ; за ред. В. І. Левченка. - Біла Церква, 2004. $-450 \mathrm{c}$.

3. Кубышкин В. А. Опухоли и кисты селезенки / В. А. Кубышкин, Д. А. Ионкин. - М. : ИД Медпрактика-М, 2007. - 288 с.

4. Локес П. І. Ультразвукова діагностика хвороб дрібних тварин / П. І. Локес, В. Г. Стовба, Л. П. Каришева. - Полтава : ФОП Говоров С. В., 2007. - C. 54-57.

5. Локес П. I. Характеристика окремих чин- сліджень у цьому напрямі.

Висновок. Ультрасонографія $є$ інформативним інструментальним допоміжним методом діагностики, що дає змогу візуалізувати та оцінити стан селезінки клінічно здорових собак та тварин $з$ патологічними змінами цього органу. Найбільш часто реєстрованими патологічними станами селезінки є спленомегалія, травми, крововиливи, розриви капсули та неоплазія (фокальна і дифузна).

ників спленомегалії у свійських собак / П. І. Локес, С. О. Кравченко // Вісник ПДАА. - Полтава : РВВ ПДАА, 2015. - №3. - С. 89-92.

6. Ультразвуковая диагностика заболеваний мелких домашних животных : [под общ. ред. П. Манниона ; пер. с англ. Д. Н. Перепелина]. М. : Аквариум-Принт, 2008. - С. 45-71.

7. Andrews $M . W$. Ultrasound of the spleen / M. W. Andrews // World S Surg. - 2000. - №24. P. 183-187.

8. Primary angiosarcoma of the spleen-CT, MR, and sonographic characteristics: report of two cases / [Vrachliotis T. G., Bennett W. F., Vaswani K. K. et al.] // Abdom. Imaging. - 2000. - V.25. - P. 283-285.

9. Surgical diseases of the spleen / [Hiatt J. R., Phillips E. H., Morgenstern L. (eds).] // Heidelberg. Springer. $-1997 .-285 \mathrm{p}$. 